\title{
Article
}

\section{Assessment of Passive vs. Active Strategies for a School Building Design}

\section{Ji Eun Kang 1, Ki Uhn Ahn ${ }^{2}$, Cheol Soo Park ${ }^{2, *}$ and Thorsten Schuetze ${ }^{3}$}

1 Department of u-City Design and Engineering, SungKyunKwan University, Suwon, Gyeonggi 16419, Korea; E-Mail: googookg@skku.edu

2 School of Civil and Architectural Engineering, SungKyunKwan University, Suwon, Gyeonggi 16419, Korea; E-Mail: ahnkiuhn@skku.edu

3 Department of Architecture, SungKyunKwan University, Suwon, Gyeonggi 16419, Korea; E-Mail: t.schuetze@skku.edu

* Author to whom correspondence should be addressed; E-Mail: cheolspark@skku.ac.kr; Tel.: +82-31-290-7567; Fax: +82-31-290-7570.

Academic Editors: Marc A. Rosen, Hendrik Tieben, Lorenzo Chelleri, York Ostermeyer and Marc Wolfram

Received: 21 August 2015 / Accepted: 6 November 2015 / Published: 16 November 2015

\begin{abstract}
This paper presents a simulation study to reduce heating and cooling energy demand of a school building in Seoul Metropolitan Area, Korea. The aim of this study was to estimate the impact of passive $v s$. active approaches on energy savings in buildings using EnergyPlus simulation. By controlling lighting, the energy saving of the original school building design was found most significant, and increased by $32 \%$ when the design was improved. It is noteworthy that energy saving potential of each room varies significantly depending on the rooms' thermal characteristics and orientation. Thus, the analysis of energy saving should be introduced at the individual space level, not at the whole building level. Additionally, the simulation studies should be involved for rational decision-making. Finally, it was concluded that priority should be given to passive building design strategies, such as building orientation, as well as control and utilization of solar radiation. These passive energy saving strategies are related to urban, architectural design, and engineering issues, and are more beneficial in terms of energy savings than active strategies.
\end{abstract}

Keywords: energy efficiency; passive; active; building design strategies; architectural engineering; energy simulation 


\section{Introduction}

The Zero Energy Building (ZEB) design has emerged as an imminent priority for designers and multi-disciplinary researchers [1,2]. A net zero-energy building (ZEB) is a residential or commercial building with greatly reduced energy needs through efficiency gains such that the balance of energy needs can be supplied with renewable technologies [3]. Definitions of ZEBs also refer, for example, to different concepts, such as "net zero energy", "zero net energy", and "net zero carbon" [4,5]. The definition of ZEB in this research refers to the definition of Torcellini et al. [3]. Torcellini et al. [3] suggests that a good ZEB should, first, be based on energy efficient design, and then utilize available renewable energy resources on site. Especially, the integration of active and passive design elements is important to achieve the required energy efficiency and productivity of a ZEB. Generally it is easier to achieve "Net Zero" Energy Buildings than "Zero" Energy Buildings [1,4]. In order to achieve a net zero energy consumption of a building over the period of one year, the total renewable energy production of a building has to either exceed, or at least be similar to, the total final energy of the concerned building.

Building Energy Performance Simulation (BEPS) tools have gained tremendous importance for analyzing energy efficient building designs since they consider the dynamic thermal behavior of buildings, climatic conditions, and user behavior [6]. Several studies [7-14] have shown that the active and passive elements can be simulated successfully for informed, rational decision-making.

Sophisticated active strategies and control logics can be simulated using BEPS. Kim et al. [7] reported that dynamic optimal control of the blind position (rolled up/down) and slat angles can be optimized for reduction of the final energy use. Boyano et al. [8] used EnergyPlus to investigate the energy saving potentials that about $28 \%$ of final energy can be saved by dimming control. Jiang et al. [9] conducted simulation studies to compare several types of the central air conditioning system with a heat recovery ventilation system [9].

With regard to passive strategies, architectural design elements, such as building shape, orientation, and window-to-wall Ratio (WWR), can significantly influence the final energy use of a building. Soussi et al. [10] used a BEPS tool to analyze the impact of passive techniques on the final energy. Gong et al. [11] used a dynamic simulation tool to investigate optimal combination of seven passive strategies (wall thickness and insulation, roof insulation, window orientation, window-to-wall ratio, glazing, overhang depth) for each of 25 cities in China. Nguyen and Reiter [12] used EnergyPlus simulation runs to find optimal passive design parameters (building shape, orientation, WWR, overhang) for a residential building, and reported that operating cost could be saved up to about $50 \%$, compared to an original design. Based on the surveyed final energy of 73 buildings from 13 countries, Ramesh et al. [13] reported that building's final energy can be significantly reduced through the use of passive and active strategies, and cautioned that an excessive use of active strategies in a building may be unproductive. Wang et al. [14] showed that the effectiveness of passive strategies can vary depending on individual rooms' thermal characteristics in a residential building.

In this paper, the authors report a ZEB project, in which the energy saving potential of active and passive design elements for a school building was evaluated using BEPS. The production of renewable energy is not discussed here. Rather, this study focuses on the enhancement of the energy efficiency and reduction of the final energy of the school building. The process achieving the ZEB concept for the concerned school building design involved the identification of effective design (or "passive") and 
control strategies (or "active"). The difference in energy efficiency between design alternatives was quantified by means of EnergyPlus [15], a widely used BEPS tool. This paper presents results and insights from the research and design project for the concerned ZEB building in Korea.

\section{Project Description}

The ZEB school building selected for the study (Figure 1, Table 1) was designed as a high school for international students in Korea. The total usable floor area of the building is $7963 \mathrm{~m}^{2}$. The building has four floors above ground and two floors below ground. The orientation of the main building is towards the southwest. Every room is equipped with an electric heat pump for cooling and heating, and LEDs for lighting. In the above-ground floors there are staff rooms, administrative rooms, and classrooms, while as in underground floors, there is a gymnasium, a cafeteria, a mechanical and electric equipment room, and music rooms with windows opening to a sunken garden. The $U$-values of building envelopes are: $0.183 \mathrm{~W} / \mathrm{m}^{2}-\mathrm{K}$ for underground walls, $0.147 \mathrm{~W} / \mathrm{m}^{2}-\mathrm{K}$ for above ground walls, $0.113 \mathrm{~W} / \mathrm{m}^{2}-\mathrm{K}$ for roofs, and $0.795 \mathrm{~W} / \mathrm{m}^{2}-\mathrm{K}$ for windows. The $\mathrm{g}$-value of the window panes is 0.442 , whereas the recommended U-values for passive house design are: $0.08-0.15 \mathrm{~W} / \mathrm{m}^{2}-\mathrm{K}$ for underground walls, $0.06-0.15 \mathrm{~W} / \mathrm{m}^{2}-\mathrm{K}$ for above ground walls and $0.8 \mathrm{~W} / \mathrm{m}^{2}-\mathrm{K}$ for windows [16]. The underground walls and g-value of windows do not meet the passive house design criterion (The g-value of windows for passive house is 0.5 ).

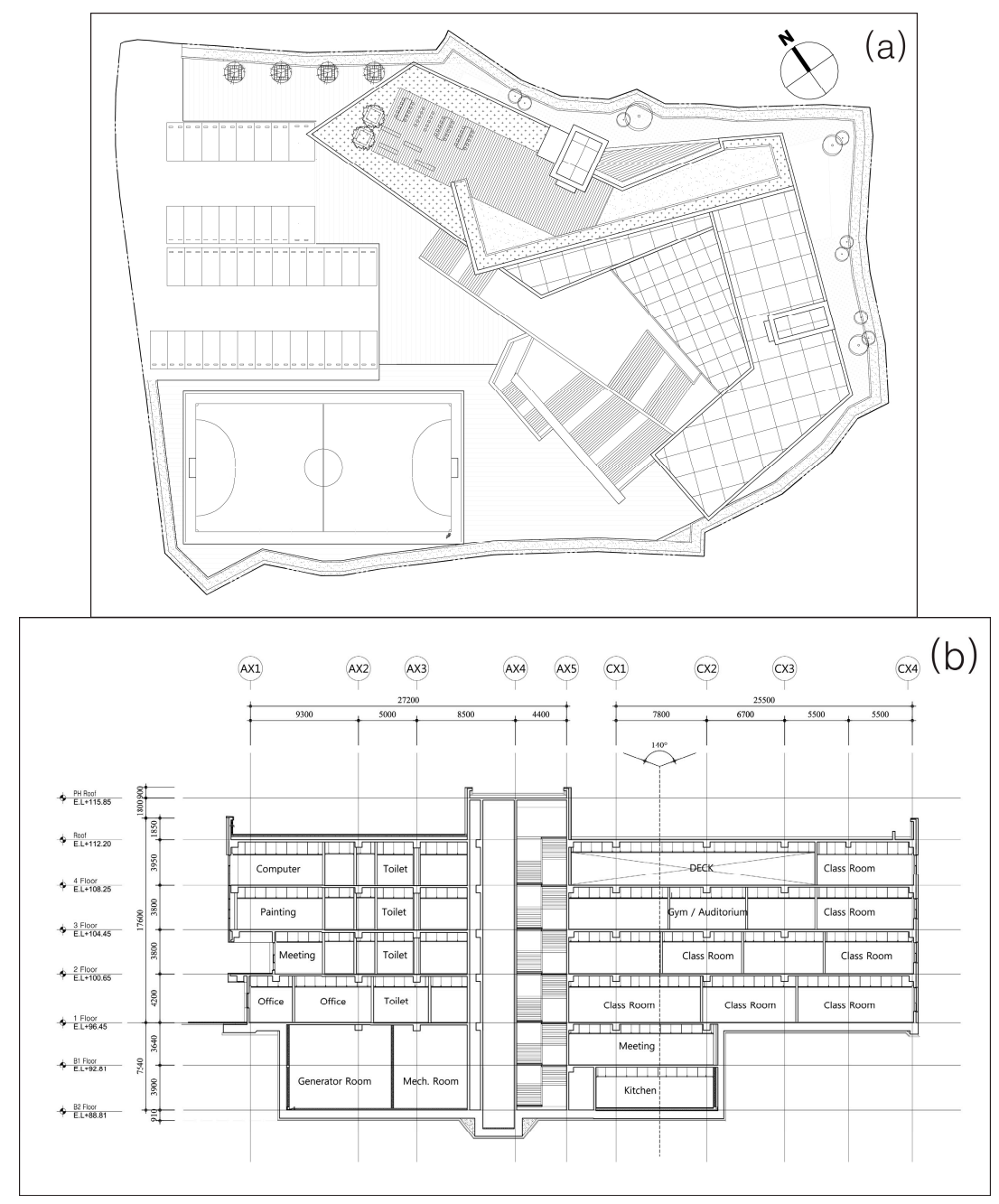

Figure 1. Cont. 


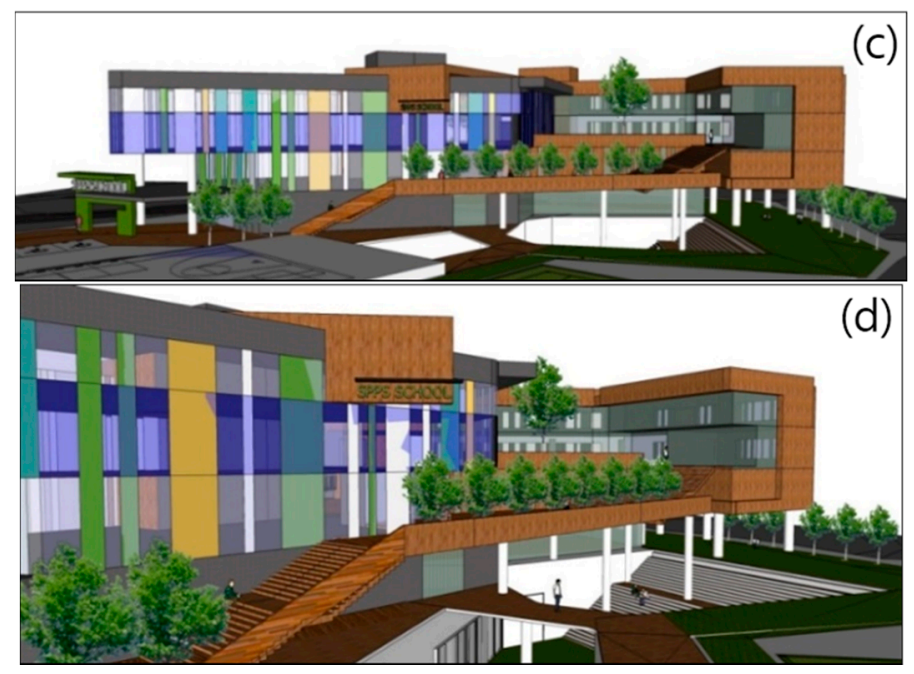

Figure 1. (a) Site plan; (b) section; (c) 3D view from southeast; and (d) 3D view from the southwest.

Table 1. Building summary.

\begin{tabular}{cc}
\hline & Description \\
\hline Location & Yongin-si, South Korea \\
\hline Orientation & Southwest \\
\hline Use & Education facility (high school) \\
\hline Stories & Basement: two floors; above ground: four floors \\
\hline Building area & Reinforced concrete \\
\hline Gross floor area & $17.6 \mathrm{~m} \mathrm{~m}^{2}$ \\
\hline Structure & for 1st floor: 4.2 m, for 2nd-4th floors: $3.8 \mathrm{~m}$ \\
\hline Building height & ventilation system without heat recovery \\
\hline Floor to floor height & Opaque: high density wood panel \\
\hline HVAC system & Transparent: triple Low-e glass \\
\hline Envelopes & Underground walls (opaque): $0.183 \mathrm{~W} / \mathrm{m}^{2}-\mathrm{K}$ \\
& Above ground walls (opaque): $0.147 \mathrm{~W} / \mathrm{m}^{2}-\mathrm{K}$ \\
U-values & Roofs (opaque): $0.113 \mathrm{~W} / \mathrm{m}^{2}-\mathrm{K}$ \\
& Windows (transparent): $0.795 \mathrm{~W} / \mathrm{m}^{2}-\mathrm{K}$ (g-value: 0.442 ) \\
\hline Number of people & 690 (students: 600, teachers and officers: 90 ) \\
\hline
\end{tabular}

The school remains open for five days a week and closes during weekends and the school holiday periods, i.e., the summer and winter vacations, which are from 27th June to 31th August, and 1st January to 3rd March, respectively. There is no specification of internal heat gains for education facilities in Korean building code. Usually, it is determined based on the engineer's judgment. Thus, the data for internal heat gains (people, lights, equipment) were assumed from the database of the program DesignBuilder (Table 2) [17]. With regard to climate data, the authors used the Seoul weather file downloaded from Weather Analytics [18]. The weather data file includes hourly weather information such as temperature, solar radiation (global, direct and diffuse), wind speed and wind direction, cloud coverage, rainfall, and relative humidity. 
Table 2. Internal heat gains from DesignBuilder database used in the model of this research.

\begin{tabular}{cccccccc}
\hline & Classroom & Office & Gymnasium & Cafeteria & Kitchen & Toilet & Ref. \\
\hline $\begin{array}{c}\text { occupant density } \\
\left(\text { person } / \mathrm{m}^{2}\right)\end{array}$ & 0.25 & 0.10 & 0.14 & 0.20 & 0.18 & 0.11 & \\
\hline $\begin{array}{c}\text { Occupants } \\
(\mathrm{W} / \text { person) }\end{array}$ & 126 & 117 & 270 & 99 & 162 & 126 & DesignBuilder [17] \\
\hline $\begin{array}{c}\text { Lights }\left(\mathrm{W} / \mathrm{m}^{2}\right) \\
\begin{array}{c}\text { Equipment } \\
\left(\mathrm{W} / \mathrm{m}^{2}\right)\end{array}\end{array}$ & 9.90 & 9.90 & 9.90 & 9.90 & 9.90 & 9.90 \\
\hline
\end{tabular}

Based on architectural drawings and specifications, the original design was simulated using the program EnergyPlus to investigate the energy efficiency (Figure 2a). The simulation results of the original school building design are shown in Table 3 and Figure $2 \mathrm{~b}$. The total annual final energy was $44.86 \mathrm{kWh} / \mathrm{m}^{2}$-year, which is in the range of the so-called low-energy buildings and is very low in comparison to conventional Korean school buildings. Due to excellent thermal performance of the building envelope, the heating and cooling final energy is relatively low, whereas the lighting final energy accounts for $44.46 \%$ (Table 3 ) of the total final energy.

Hence, reducing the energy use for artificial lighting became a priority for further reduction of the building's total final energy. Based on Table 3, the authors developed active design strategies for the reduction of the building's total final energy, which will be explained in the following section.

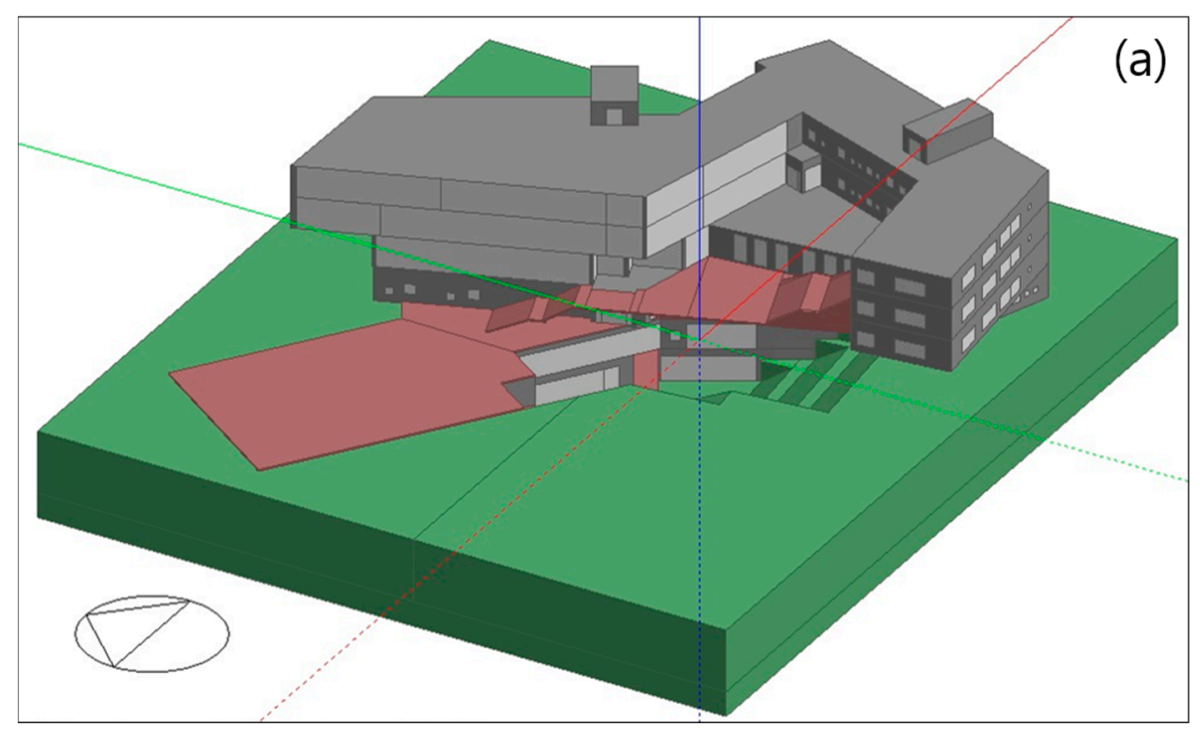

Figure 2. Cont. 


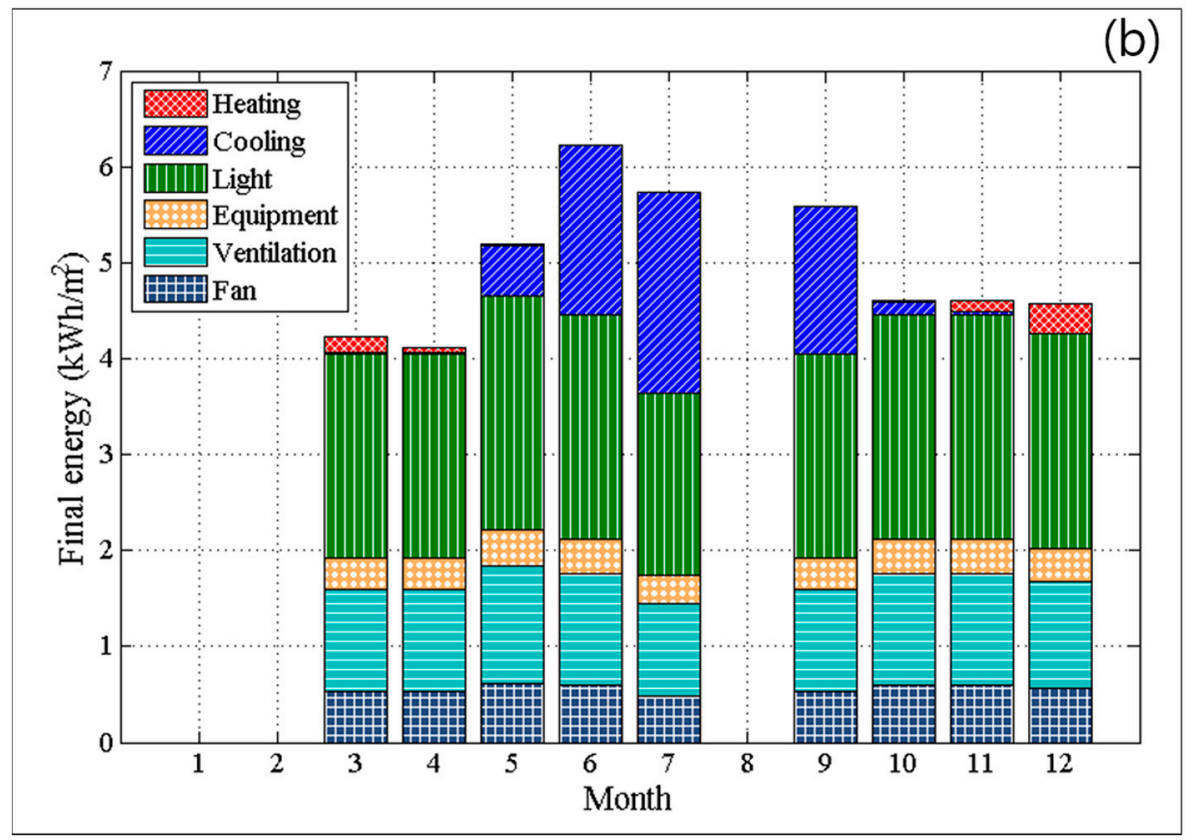

Figure 2. (a) Simulation model; and (b) final energy of the original school design.

Table 3. Annual final energy of the original design.

\begin{tabular}{cccccccc}
\hline & Heating & Cooling & Lighting & Equipment & Ventilation & Fan & Total \\
\hline $\mathrm{kWh} / \mathrm{m}^{2}$-year & 0.69 & 6.10 & 19.95 & 3.10 & 10.00 & 5.03 & 44.86 \\
$\%$ & 1.53 & 13.60 & 44.46 & 6.90 & 22.29 & 11.22 & 100.00 \\
\hline
\end{tabular}

\section{Active Strategies}

\subsection{Application of Active Strategies}

The initial building design was already completed, and since passive strategies (change of orientations, window-to-wall ratio, room relocation, etc.) require significant effort and time to redesign the school, the active strategies were applied first in order to reduce the building's final energy. Since the original school design is equipped with excellent thermal performance of the building envelope (Table 3), it is assumed that an excessive use of active strategies in the building may be unproductive [13]. In this regard intelligent lighting control was considered primarily in addition to dynamic blinds and controlled ventilation systems with heat recovery. These three active design strategies are summarized as follows:

- Blinds-dynamic exterior blinds: in cooling mode, blinds are closed (rolled down) to block incident solar radiation. In heating mode at daytime, blinds are rolled up to allow solar radiation as much as possible. During night time, blinds are rolled down to minimize escape of long-wave radiation through glazing surfaces to outdoors environment (e.g., a cold night sky).

- Lights - day lighting autonomy: if illuminance of indoor daylight is higher than the threshold (classroom: 400 lx, office: 300 lx), the artificial lighting is automatically turned off. If it is lower than the threshold, three steps of dimming control are applied (33\%, 66\%, and 100\%).

- Heat Exchanger (HE) - controlled ventilation with heat recovery: in the original design, there was a mechanical ventilation system without heat recovery. Hence, a $\mathrm{CO}_{2}$ level-controlled 
mechanical ventilation system with HE was introduced for energy savings. In both cases (the base case, as well as the active HE case), the ventilation rate was set to $9.44 \mathrm{~L} / \mathrm{s}$-person. The heat recovery efficiency of the $\mathrm{HE}$ system with regard to total heat (both sensible and latent) was 0.8 . In addition, when outdoor air temperature is between $10{ }^{\circ} \mathrm{C}$ and $23{ }^{\circ} \mathrm{C}$, the $\mathrm{HE}$ is not operated and works in bypass economizer mode, thereby saving energy.

\subsection{Results}

Table 4 and Figure 3 show the simulation results of active design strategies. The lighting control strategy could save $28.07 \%$ of total annual final energy by reducing $25 \%$ of the cooling final energy and $55 \%$ of the lighting final energy. The cooling final energy can be significantly reduced by dynamic blinds and lighting control. In contrast, the heating final energy increases since the exterior blinds prevent transmission of part of solar radiation, and lighting control reduces heat gain from luminaries.

The introduction of controlled ventilation system with HE was efficient in heating mode, but increased the cooling final energy due to the entry of hot and humid outdoor air during the summer.

Table 4. Annual final energy simulation results of active strategies $\left(\mathrm{kWh} / \mathrm{m}^{2}\right.$-year).

\begin{tabular}{ccccccccc}
\hline & Heating & Cooling & Lighting & Equipment & Ventilation & Fan & Total & Saving (\%) \\
\hline Original & 0.69 & 6.10 & 19.95 & 3.10 & 10.00 & 5.03 & 44.86 & - \\
Blinds & 1.02 & 4.51 & 19.95 & 3.10 & 10.00 & 3.35 & 41.92 & 6.57 \\
Lights & 1.07 & 4.89 & 8.88 & 3.10 & 10.00 & 4.33 & 32.27 & 28.07 \\
HE & 0.22 & 7.01 & 19.95 & 3.10 & 10.00 & 5.03 & 45.30 & -0.99 \\
\hline
\end{tabular}

The results shown in Table 4 and Figure 3 are based on the simulation of the entire building. The energy saving potential of each active design strategy varies significantly depending on thermal characteristics of room type and orientation. Four classrooms and offices were randomly selected for this purpose, as shown in Table 5 .

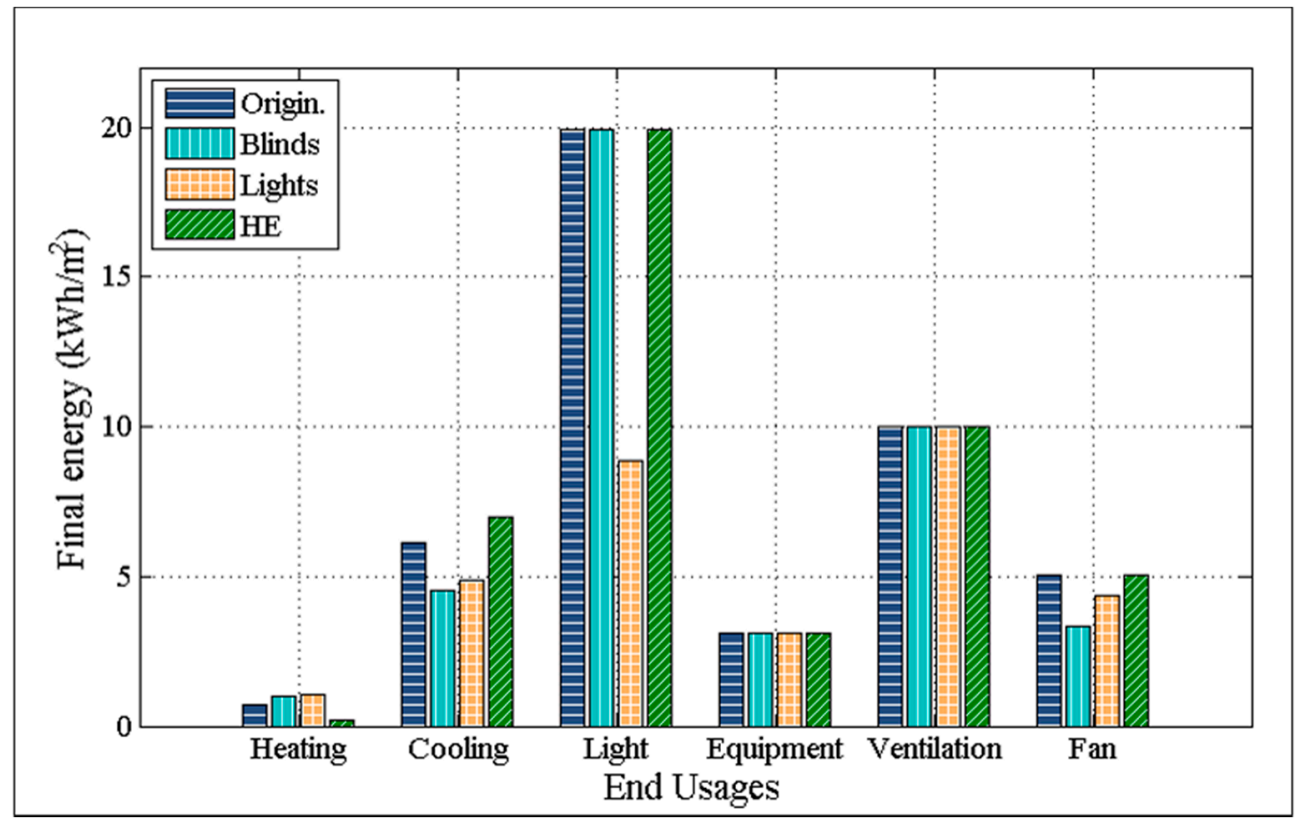

Figure 3. Annual final energy simulation results of active strategies $\left(\mathrm{kWh} / \mathrm{m}^{2}\right.$-year). 
The interesting findings as illustrated in Tables 5 and 6 are as follows:

- Energy saving potential of dynamic blinds and artificial lighting control is significantly influenced by the room's orientation, WWR, and the specific season related to the investigated months $($ January $=$ Winter, May $=$ Spring, August $=$ Summer $)$. For example, blinds and lighting controls are most suited to Room \#7 since it faces south and has 100\% WWR.

- Controlled ventilation with heat recovery by Heat Exchanger (HE) is most advantageous to classrooms because the required ventilation rate is higher than the required outdoor rate of the offices due to the high density of students. Interestingly, the HE proved to be inappropriate to Room 7 which has a south glazed façade (Table 5). The 100\% glazed south façade in Room 7 allows transmission of significant solar radiation in January enough to heat the space. Thus, the HE is counterproductive throughout the year for Room 7.

- The energy saving analysis of the aforementioned strategies (blinds, lights, and HE) should be done at the level of the individual space, not at the level of the whole building. For example, the $\mathrm{HE}$ is least effective if assessed at the whole building level (Table 4), but it can be regarded as the best energy saving strategy in all classrooms during January (Table 6).

- Energy savings depends not only on the strategies but also on the room's thermal characteristics like WWR, the portion of specific air-conditioning modes (cooling vs. heating), the required artificial lighting level, ventilation rate, etc. Rather than following a designer's intuition or an expert's judgment, simulation studies must be involved for informed rational design.

Table 5. Floor area and window-to-wall ratio (WWR) of classrooms and offices.

\begin{tabular}{ccccccccc}
\hline & \multicolumn{4}{c}{ Classrooms } & \multicolumn{4}{c}{ Offices } \\
\cline { 2 - 9 } & Room1 & Room2 & Room3 & Room4 & Room5 & Room6 & Room7 & Room8 \\
\hline Orientation & East & West & South & North & East & West & South & North \\
Floor area $\left(\mathrm{m}^{2}\right)$ & 127.68 & 134.44 & 121.67 & 161.09 & 57.24 & 97.33 & 60.90 & 50.86 \\
WWR $(\%)$ & 23.0 & 47.6 & 26.4 & 20.5 & 12.2 & 13.5 & 100.0 & 13.9 \\
\hline
\end{tabular}

Table 6. Final energy and savings of classrooms and offices.

\begin{tabular}{|c|c|c|c|c|c|c|c|c|c|}
\hline \multirow{2}{*}{\multicolumn{2}{|c|}{ Room \# }} & \multirow[b]{2}{*}{ Season } & \multirow{2}{*}{$\begin{array}{c}\text { Original } \\
\text { Energy } \\
(\mathrm{kWh}) \\
\end{array}$} & \multicolumn{2}{|c|}{ Blinds } & \multicolumn{2}{|c|}{ Lights } & \multicolumn{2}{|c|}{ HE } \\
\hline & & & & $\begin{array}{l}\text { Energy } \\
(k W h)\end{array}$ & $\begin{array}{c}\text { Saving } \\
(\%)\end{array}$ & $\begin{array}{l}\text { Energy } \\
(k W h)\end{array}$ & $\begin{array}{c}\text { Saving } \\
(\%)\end{array}$ & $\begin{array}{c}\text { Energy } \\
(\mathrm{kWh})\end{array}$ & $\begin{array}{c}\text { Saving } \\
(\%)\end{array}$ \\
\hline \multirow{12}{*}{ Classrooms } & \multirow{3}{*}{ Room 1} & January & 84 & 85 & -1.2 & 78 & 7.2 & 45 & 46.0 \\
\hline & & May & 128 & 102 & 20.6 & 89 & 30.8 & 130 & -1.3 \\
\hline & & August & 172 & 145 & 15.9 & 129 & 24.9 & 167 & 2.9 \\
\hline & \multirow{3}{*}{ Room 2} & January & 96 & 96 & -0.3 & 91 & 5.0 & 53 & 44.8 \\
\hline & & May & 161 & 104 & 35.4 & 116 & 27.8 & 163 & -1.1 \\
\hline & & August & 212 & 149 & 29.8 & 166 & 21.8 & 206 & 2.9 \\
\hline & \multirow{3}{*}{ Room 3} & January & 74 & 74 & -0.8 & 61 & 17.5 & 42 & 43.4 \\
\hline & & May & 114 & 91 & 19.8 & 81 & 28.6 & 115 & -1.4 \\
\hline & & August & 162 & 135 & 16.7 & 130 & 19.4 & 157 & 2.8 \\
\hline & \multirow{3}{*}{ Room 4} & January & 111 & 112 & -1.0 & 103 & 6.8 & 57 & 48.1 \\
\hline & & May & 154 & 125 & 18.9 & 99 & 35.6 & 156 & -1.2 \\
\hline & & August & 209 & 179 & 14.7 & 153 & 26.9 & 202 & 3.4 \\
\hline
\end{tabular}


Table 6. Cont.

\begin{tabular}{|c|c|c|c|c|c|c|c|c|c|}
\hline \multirow{2}{*}{\multicolumn{2}{|c|}{ Room \# }} & \multirow[b]{2}{*}{ Season } & \multirow{2}{*}{$\begin{array}{c}\text { Original } \\
\text { Energy } \\
(\mathrm{kWh})\end{array}$} & \multicolumn{2}{|c|}{ Blinds } & \multicolumn{2}{|c|}{ Lights } & \multicolumn{2}{|c|}{ HE } \\
\hline & & & & $\begin{array}{c}\text { Energy } \\
(\mathrm{kWh})\end{array}$ & $\begin{array}{c}\text { Saving } \\
(\%)\end{array}$ & $\begin{array}{l}\text { Energy } \\
(\mathrm{kWh})\end{array}$ & $\begin{array}{c}\text { Saving } \\
(\%)\end{array}$ & $\begin{array}{l}\text { Energy } \\
(\mathrm{kWh})\end{array}$ & $\begin{array}{c}\text { Saving } \\
(\%)\end{array}$ \\
\hline \multirow{12}{*}{ Offices } & \multirow{3}{*}{ Room 5} & January & 82 & 82 & 0.9 & 82 & 0.4 & 77 & 6.1 \\
\hline & & May & 71 & 59 & 17.7 & 52 & 27.3 & 72 & -1.3 \\
\hline & & August & 85 & 72 & 15.7 & 64 & 24.5 & 86 & -0.8 \\
\hline & \multirow{3}{*}{ Room 6} & January & 80 & 79 & 0.7 & 80 & 0.0 & 68 & 15.1 \\
\hline & & May & 100 & 92 & 8.3 & 92 & 8.6 & 101 & -0.9 \\
\hline & & August & 124 & 114 & 7.9 & 113 & 8.7 & 123 & 1.0 \\
\hline & \multirow{3}{*}{ Room 7} & January & 26 & 26 & 0.9 & 17 & 35.7 & 28 & -9.1 \\
\hline & & May & 150 & 81 & 45.9 & 129 & 13.9 & 151 & -0.6 \\
\hline & & August & 181 & 101 & 44.3 & 159 & 11.8 & 181 & -0.4 \\
\hline & \multirow{3}{*}{ Room 8} & January & 50 & 49 & 1.2 & 49 & 2.7 & 42 & 15.9 \\
\hline & & May & 74 & 61 & 17.0 & 54 & 26.6 & 75 & -1.2 \\
\hline & & August & 86 & 73 & 14.8 & 66 & 23.3 & 88 & -2.1 \\
\hline
\end{tabular}

\section{Passive Strategies}

\subsection{Application of Passive Strategies}

In the original building design, most rooms on the 2 nd floor of the building have almost $100 \%$ of WWR. In addition, most classrooms and staff rooms are located on both sides of the corridor facing different directions, east, west, or north. The gymnasium and music rooms are located underground, without any windows and always require artificial lights turned on at daytime.

Even though the active design strategies discussed in Section 3 show significant energy saving potentials, the authors decided to re-design the building to correct the aforementioned issues, such as improvement of WWR and day lighting potential of all rooms, thus aiming to identify how much more energy could be saved by the application of passive design strategies in the re-design of the concerned school building.

Figure 4 shows the site plan, section and 3D of the re-designed school building. The aim was to keep the size of the re-designed building as similar as possible to that of the original building design. In order to not reduce the final energy demand of the re-designed building by reduction of floor areas, the re-design goal was to provide at least the similar number and floor area of rooms, usable areas, and ceiling heights. The re-designed school building was more cubic and compact (Figure 4) than the original, which was long and narrow in terms of shape and design (Figures 1 and 2). In order to facilitate day lighting of central spaces and rooms the re-designed building was equipped with an atrium in the center of the building. The floor-to-floor story height of the redesign could be reduced by the avoidance of suspended ceilings in the rooms (Figure 4) compared with the original design (Figure 1). Due to the redesign of the building shape both the volume and the usable areas of corridor and atrium space increased, even though the room space is similar to the original design and the both design cater to the needs of the same amount of people.

The comparison of the area, volume and WWR between the original and re-designed school building is shown in Table 7. The floor area of the re-designed building was greater than that of the original 
design (re-design: $8573 \mathrm{~m}^{2}$ (108\%), original: $7963 \mathrm{~m}^{2}$ (100\%)). The improved U-values of building envelopes of the re-design are as follows: $0.120 \mathrm{~W} / \mathrm{m}^{2}-\mathrm{K}$ for underground walls, $0.111 \mathrm{~W} / \mathrm{m}^{2}-\mathrm{K}$ for the walls above ground and $0.111 \mathrm{~W} / \mathrm{m}^{2}-\mathrm{K}$ for the roof. The U-value and SHGC of windows of the re-design are same as those of the original design.

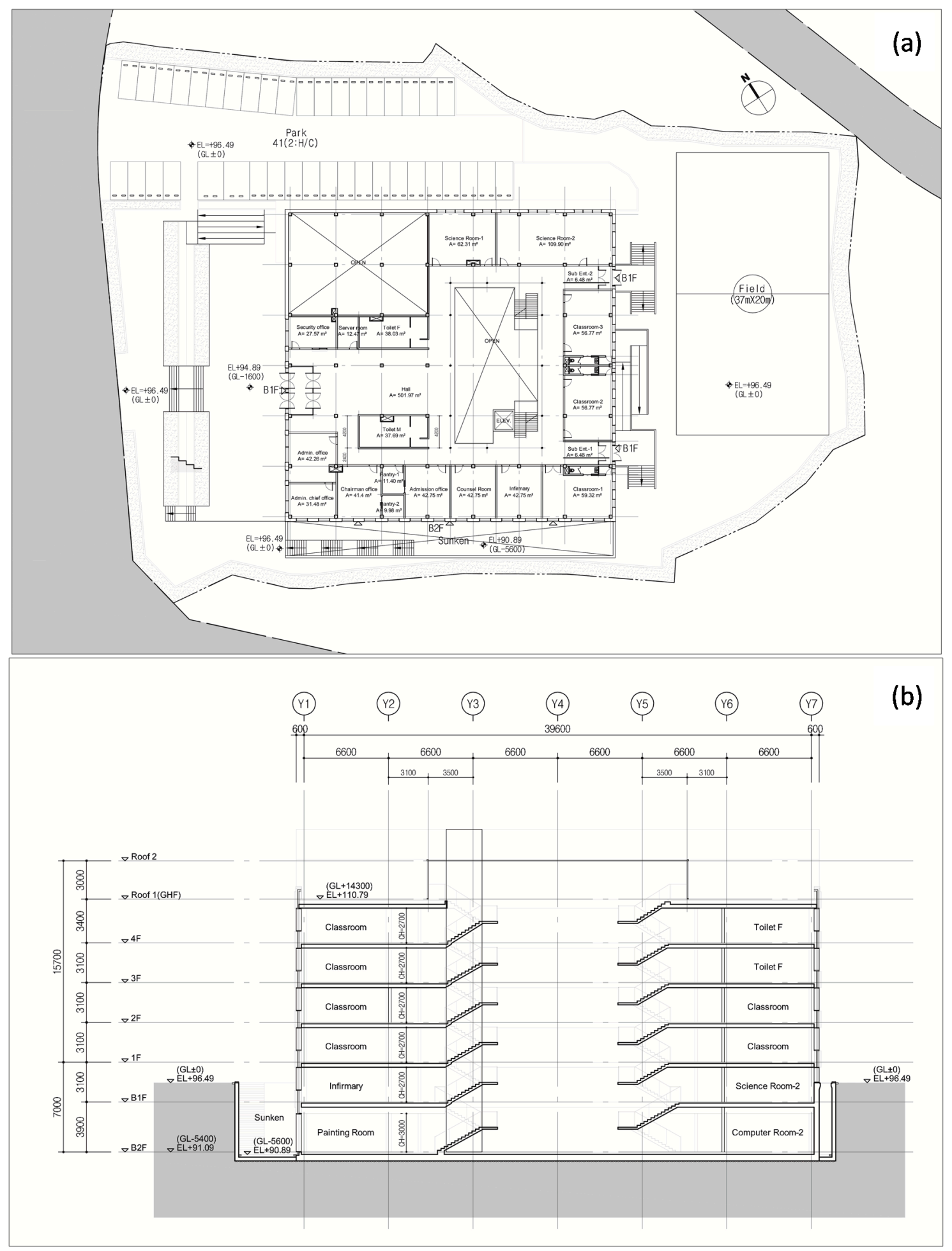

Figure 4. Cont. 


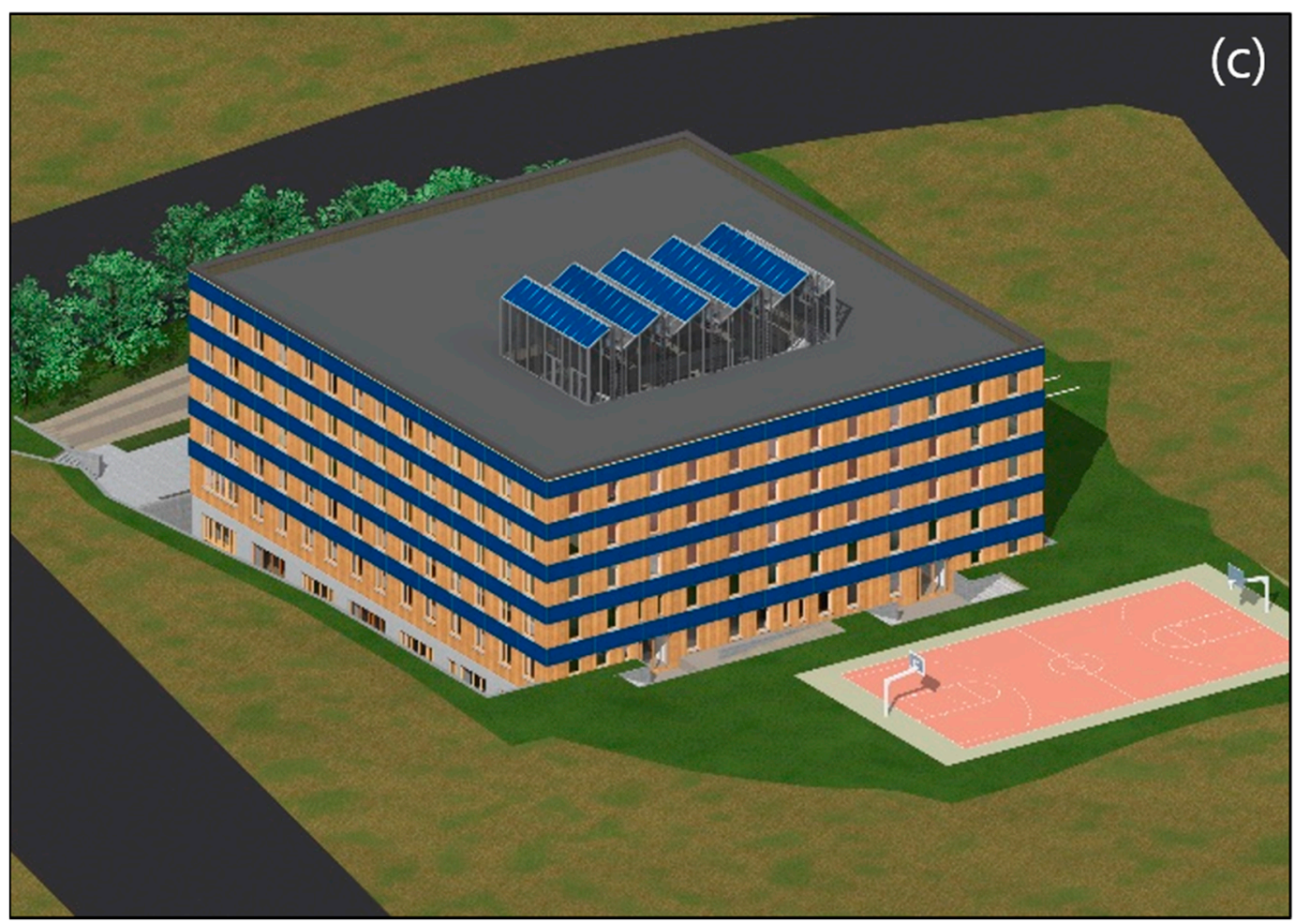

Figure 4. (a) Site plan; (b) section; and (c) 3D picture from the southeast.

Table 7. Comparison of area, volume and WWR of the original and re-designed school building.

\begin{tabular}{cccccc}
\hline & $\begin{array}{c}\text { Total Floor } \\
\text { Area }\left(\mathbf{m}^{\mathbf{2}}\right)\end{array}$ & $\begin{array}{c}\text { Exterior Envelop } \\
\text { Area }\left(\mathbf{m}^{\mathbf{2}}\right)\end{array}$ & WWR (\%) & $\begin{array}{c}\text { Conditioned } \\
\text { Area }\left(\mathbf{m}^{\mathbf{2}}\right)\end{array}$ & $\begin{array}{c}\text { Conditioned } \\
\text { Volume }\left(\mathbf{m}^{\mathbf{3}}\right)\end{array}$ \\
\hline Original design & $7693(100 \%)$ & $1958(100 \%)$ & $28.24(100 \%)$ & $4599(100 \%)$ & $19,841(100 \%)$ \\
Re-design & $8573(108 \%)$ & $1733(89 \%)$ & $29.44(104 \%)$ & $4955(108 \%)$ & $16,079(81 \%)$ \\
\hline
\end{tabular}

\subsection{Results}

The dynamic building simulation that was conducted on the re-designed school building with the program EnergyPlus shows the following results. The amount of final energy consumption of different uses in specific months is illustrated in Figure $5 \mathrm{~b}$.

The annual energy consumption of the re-design is $30.47 \mathrm{kWh} / \mathrm{m}^{2}$, leading to savings in the final energy of $32 \%$ compared with the original school building design (Table 8 ). The calculated savings were achieved without including the active design strategies discussed in Section 3. The percentages of the final energy for specific uses in relation to the total annual final energy are illustrated in Table 8 . The results show that percentages in relation to total are similar to the original school design (Table 3 ). 

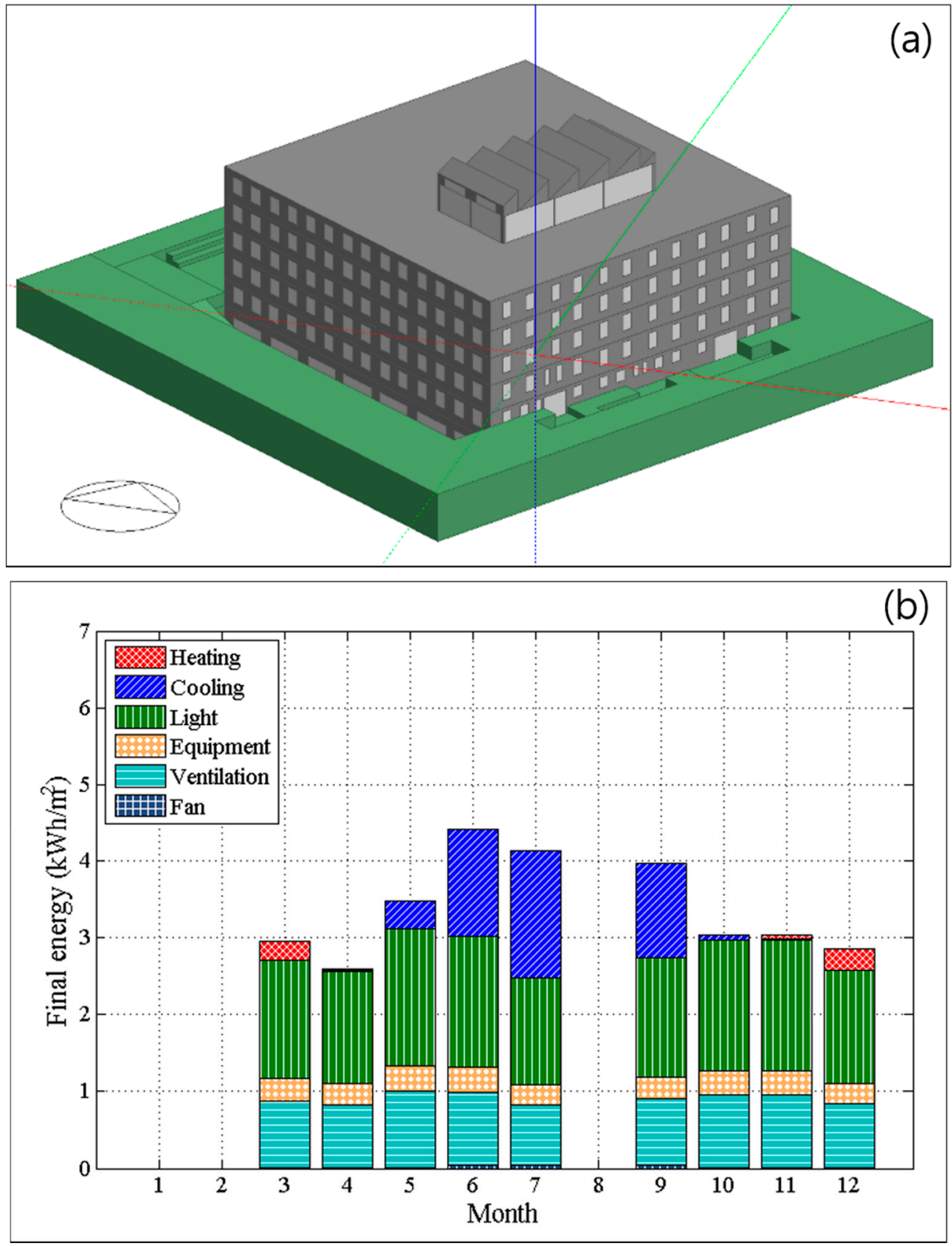

Figure 5. (a) Simulation model; and (b) final energy of the re-designed school.

Table 8. Annual final energy of the re-design.

\begin{tabular}{cccccccc}
\hline & Heating & Cooling & Lighting & Equipment & Ventilation & Fan & Total \\
\hline $\mathrm{kWh} / \mathrm{m}^{2}$-year & 0.60 & 4.73 & 14.29 & 2.65 & 8.04 & 0.15 & 30.47 \\
$\%$ & 1.96 & 15.52 & 46.91 & 8.70 & 26.40 & 0.50 & 100.00 \\
\hline
\end{tabular}

\section{Integration of Active and Passive Strategies}

The active design strategies discussed in Section 3.1 were also applied to the re-designed school building. Table 9 and Figure 6 show the simulation results. The energy saving potential (\%) of each active design strategy (Table 9) of the re-designed school building is similar to the percentages presented in Table 4. As shown in Tables 4 and 9, the lighting control is most advantageous. It is noteworthy that 
the energy consumption of the passive design $\left(30.47 \mathrm{kWh} / \mathrm{m}^{2}\right.$-year) is better than the best active strategy (lighting control) in the original design $\left(32.27 \mathrm{kWh} / \mathrm{m}^{2}\right.$-year). When lighting control is applied to the re-design, the energy consumption is reduced to $21.82 \mathrm{kWh} / \mathrm{m}^{2}$-year, which is close to energy saving rate of $51.36 \%$ (Table 10 ).

Table 9. Annual final energy simulation results of the re-design with active strategies $\left(\mathrm{kWh} / \mathrm{m}^{2}\right.$-year $)$.

\begin{tabular}{ccccccccc}
\hline & Heating & Cooling & Lighting & Equipment & Ventilation & Fan & Total & Saving (\%) \\
\hline Passive design & 0.60 & 0.73 & 14.29 & 2.65 & 8.04 & 0.15 & 30.47 & - \\
Blinds & 0.82 & 3.91 & 14.29 & 2.65 & 8.04 & 0.13 & 29.85 & 2.03 \\
Lights & 0.85 & 3.85 & 6.30 & 2.65 & 8.04 & 0.13 & 21.82 & 28.39 \\
HE & 0.06 & 5.36 & 14.29 & 2.65 & 8.04 & 0.15 & 30.56 & -0.31 \\
\hline
\end{tabular}

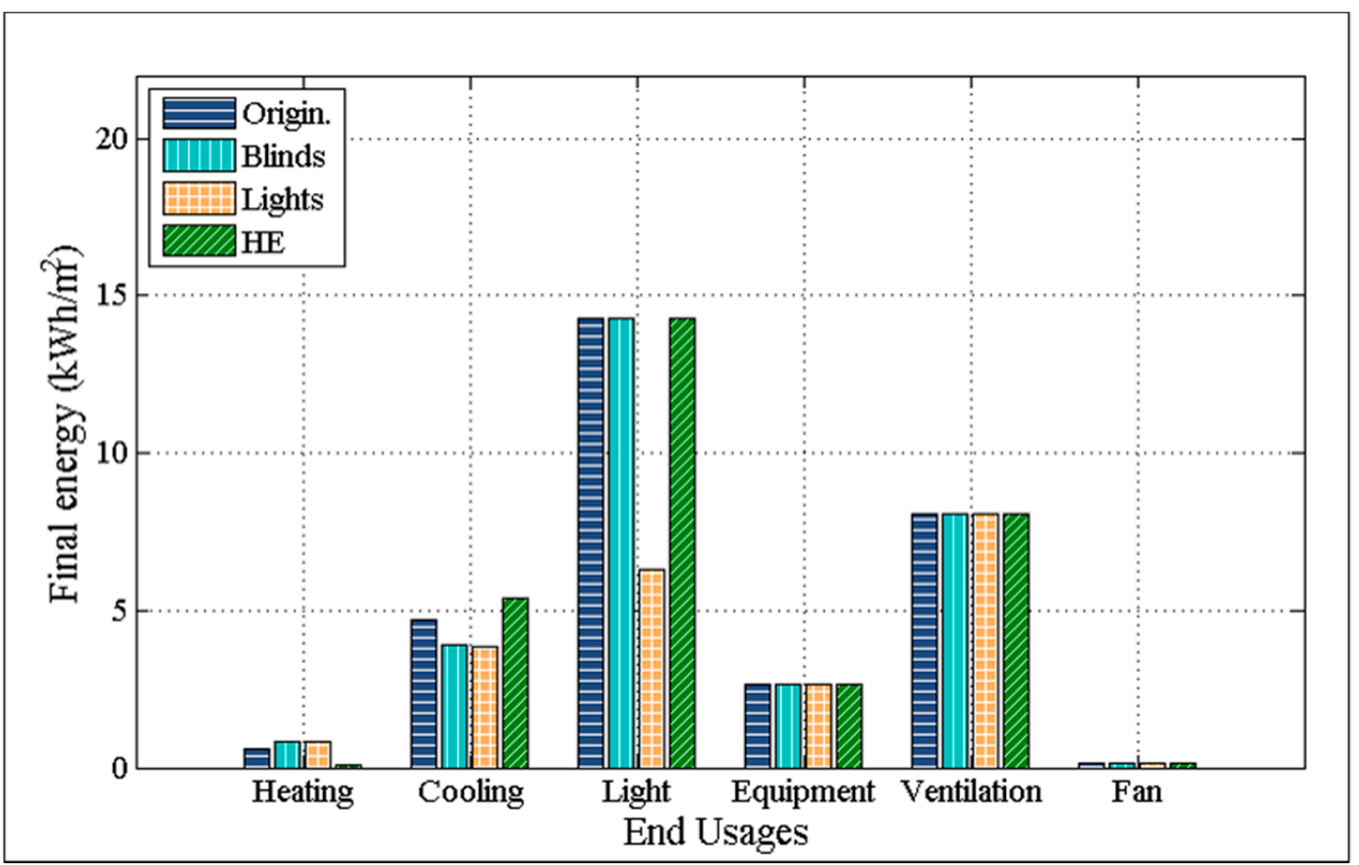

Figure 6. Annual final energy simulation results of the re-design with active strategies $\left(\mathrm{kWh} / \mathrm{m}^{2}\right.$-year).

Table 10. Integration of active and passive strategies.

\begin{tabular}{ccccccc}
\hline & $\begin{array}{c}\text { Original } \\
\text { Design }\end{array}$ & \multicolumn{2}{c}{$\begin{array}{c}\text { Original Design with Active } \\
\text { Strategies (Active only) }\end{array}$} & \multirow{2}{*}{$\begin{array}{c}\text { Re-Design } \\
\text { (Passive only) }\end{array}$} & \multicolumn{2}{c}{$\begin{array}{c}\text { Re-Design with Active } \\
\text { Strategies (Passive \& } \\
\text { Active together) }\end{array}$} \\
\cline { 3 - 4 } & Best (Lights) & Worst (HE) & & & Best (Lights) & Worst (HE) \\
\hline $\begin{array}{c}\text { Energy } \\
\left(\mathrm{kWh} / \mathrm{m}^{2}\right)\end{array}$ & 44.86 & 32.27 & 45.30 & 30.47 & 21.82 & 30.56 \\
\hline Saving $(\%)$ & - & 28.07 & -0.99 & 32.08 & 51.36 & 31.88 \\
\hline
\end{tabular}

According to the findings the effectiveness of active strategies regarding the reduction of the total final energy vary significantly between the original school design and the re-design. For instance, the 
final energy saving rate by application of dynamic blinds on the original school design is $6.57 \%$, while the energy saving by application of dynamic blinds on the re-designed school building is only $2.03 \%$.

\section{Conclusions}

This study addresses a ZEB school design project with application and comparison of passive and active design strategies for the reduction of the building's final energy. The following important findings were derived from the study:

- Passive building design strategies should primarily be addressed since they are more efficient in terms of energy savings than active strategies. The re-designed school building according to passive design strategies, and without the application of active design strategies analyzed in this study, had lower final energy $\left(30.47 \mathrm{kwh} / \mathrm{m}^{2}\right.$-year) than the original school design with active design strategies applied (44.86 [original design], 41.92 [blinds], 32.27 [lights], 45.30 [HE] $\mathrm{kwh} / \mathrm{m}^{2}$-year, Table 4). The results confirm the assumption that an excessive use of active strategies in the building may be unproductive.

- Energy saving potentials of active strategies are significantly influenced by the room's thermal characteristics, such as orientation, WWR, dominant air-conditioning mode (cooling vs. heating), required ventilation rate $(\mathrm{L} / \mathrm{s})$, illuminance level, etc. In case of HE, \% energy savings ranges from $-2.1 \%$ for room $\# 8$ to $48.1 \%$ for room \#4 (Table 6). Therefore, special attention should be paid to the selection of active strategies depending on the different room's thermal characteristics analysis and simulation results.

- The energy saving analysis should be introduced at the level of individual space, not at the level of the whole building. Additionally, building simulation studies must be involved for informed, rational design and control (Table 6).

- All the active strategies are simulated at the individual room level in this study. In Korea, the EHP system is mostly coupled with an individual HE since the EHP does not bring the outdoor air into indoor space. Furthermore, individual HE can be installed in rooms where the simulation results prove the effectiveness of mechanical ventilation systems with HE without the need to install mechanical ventilation systems with HE on the central level.

\section{Acknowledgments}

This research was supported by a grant (11 AUDP G02) from Architecture \& Urban Development Research Program funded by Ministry of Land, Infrastructure and Transport of Korean government.

\section{Author Contributions}

Ji-Eun Kang, Ki-Uhn Ahn and Cheol Soo Park performed the energy simulation study and analyzed the data together. Thorsten Schuetze made a leading role of the ZEB project and conducted the re-design of the original school building with Ji-Eun Kang. 


\section{Conflicts of Interest}

The authors declare no conflict of interest.

\section{References}

1. Marszal, A.J.; Heiselberg, P.; Bourrelle, J.S.; Musall, E.; Voss, K.; Sartori, I.; Napolitano, A. Zero Energy Building - A review of definitions and calculation methodologies. Energy Build. 2011, 33, 971-979.

2. Wang, L.; Gwilliam, J.; Jones, P. Case study of zero energy house design in UK. Energy Build. 2009, 41, 1215-1222.

3. Torcellini, P.; Pless, S.; Deru, M.; Crawely, D. Zero Energy Buildings: A Critical Look at the Definition. In Proceedings of the ACEEE Summer Study on Energy Efficiency in Buildings, Pacific Grove, CA, USA, 14-18 August 2006.

4. Voss, K.; Musall, E.; Lichtmeß, M. From Low Energy Buildings to Net Zero-Energy Buildings: Status and Perspecives. J. Green Build. 2011, 6, 12.

5. Voss, K.; Musall, E. Net Zero Energy Buildings, 2nd ed.; Detail, Institut für Internationale Architektur-Dokumentation GmbH \& Co. KG: Munich, Germany, 2012.

6. Loonen, R.C.G.M.; Singaravel, S.; Trčka, M.; Cóstola, D.; Hensen, J.L.M. Simulation-based support for product development of innovative building envelop components. Autom. Constr. 2014, 45, 86-95.

7. Kim, D.W.; Park, C.S. Comparative control strategies of exterior and interior blind systems. Light. Res. Technol. 2012, 44, 291-308.

8. Boyano, A.; Hernandez, P.; Wolf, O. Energy demands and potential savings in European office buildings: Case studies based on EnergyPlus simulations. Energy Build. 2013, 65, 19-28.

9. Jiang, Y.; Ge, T.S.; Wang, R.Z. Comparison study of a novel solid desiccant heat pump system with energyplus. Build. Simul.-China 2014, 7, 467-476.

10. Soussi, M.; Balghouthi, M.; Guizani, A. Energy performance analysis of a solar-cooled building in Tunisia: Passive strategies impact and improvement techniques. Energy Build. 2013, 67, 374-386.

11. Gong, X.Z.; Akashi, Y.; Sumiyoshi, D. Optimization of passive design measures for residential buildings in different Chinese areas. Build. Environ. 2012, 58, 46-57.

12. Nguyen, A.T.; Reiter, S. Passive designs and strategies for low-cost housing using simulation-based optimization and different thermal comfort criteria. J. Build. Perform. Simul. 2014, 7, 68-81.

13. Ramesh, T.; Prakash, R.; Shukla, K.K. Life cycle energy analysis of buildings: An overview. Energy Build. 2010, 42, 1592-1600.

14. Wang, Q.; Zhang, Y.; Ahuja, S.; Augenbroe, G. Re-evaluation of passive design measures in the BASF house in recognition of uncertainty and model discrepancy. In Proceedings of the 30th International PLEA Conference, Ahmedabad, India, 16-18 December 2014.

15. EnergyPlus. EnergyPlus Manual; Department of Energy: Washington, DC, USA, 2015.

16. International Passive House Association (IPHA). Available online: http://www.passivehouseinternational.org/ (accessed on 10 August 2015).

17. DesignBuilder. Available online: http://www.designbuilder.co.uk (accessed on 10 August 2015). 
18. Weather Analytics. Available online: http://www.weatheranalytics.com/ (accessed on 14 September 2015).

(C) 2015 by the authors; licensee MDPI, Basel, Switzerland. This article is an open access article distributed under the terms and conditions of the Creative Commons Attribution license (http://creativecommons.org/licenses/by/4.0/). 